\title{
L-Arginine is essential for the formation in vitro of ethylene by an extract of Pseudomonas syringae
}

\author{
Kazuhiro Nagahama, ${ }^{1}$ Takahira Ogawa, ${ }^{1}$ Takao Fujil, ${ }^{1}$ Masato Tazaki, ${ }^{2}$ Masao Goto ${ }^{3}$ \\ and HIDEO FUKUDA ${ }^{1 *}$ \\ ${ }^{1}$ Departments of Applied Microbial Technology and ${ }^{2}$ Industrial Chemistry, The Kumamoto Institute of Technology, \\ Ikeda 4-22-1, Kumamoto 860, Japan \\ ${ }^{3}$ Faculty of Agriculture, Shizuoka University, 836 Ohya, Shizuoka 422, Japan
}

(Received 5 November 1990; revised 25 January 1991; accepted 25 March 1991)

\begin{abstract}
A system was developed for the formation of ethylene in vitro by an extract of Pseudomonas syringae pv. phaseolicola PK2. The ethylene-forming activity of a cell-free extract of this bacterium measured in a system reported previously was almost completely lost when the cell-free extract was dialysed against potassium phosphate buffer for $24 \mathrm{~h}$ at $4^{\circ} \mathrm{C}$. When the fraction of cell-free extract with a molecular mass $<10 \mathrm{kDa}$ (SupI) was added back to the enzyme fraction after gel filtration of the cell-free extract, the enzymic activity increased to about four times that of the gel-filtered crude enzyme. The action of SupI could be reproduced by the addition of $\mathrm{L}$-arginine. The complete system for the formation of ethylene under aerobic conditions in vitro required $0.25 \mathrm{mM}$ 2-oxoglutarate, $0.2 \mathrm{mM}-\mathrm{FeSO}_{4}, 2 \mathrm{mM}-\mathrm{DTT}, 10 \mathrm{mM}$-L-histidine and 0.2 mM-L-arginine. The cofactor specificity was examined by replacing $L$-arginine or $L$-histidine with various analogues, but none of them were effective. The components of this system, with the exception of $L$-histidine, were similar to those of a system derived from the ethylene-producing, plant pathogenic fungus Penicillium digitatum which also produced ethylene in vitro in a reaction dependent on 2-oxoglutarate. The intermediates in the ethylene-forming reaction are postulated and the roles of L-arginine and L-histidine in the formation of ethylene by Ps. syringae are discussed.
\end{abstract}

\section{Introduction}

There are two biosynthetic pathways that lead to ethylene production in micro-organisms. One pathway involves 2-oxoglutarate (Fukuda et al., 1986, 1989a) and the other 2-keto-4-methylthiobutyric acid (KMBA) (Fukuda et al., 1989b, c; Ogawa et al., 1990). We refer to organisms that use the former pathway as 2-oxoglutarate-dependent ethylene-producing micro-organisms, e.g. Penicillium digitatum, and to organisms that use the latter pathway as methionine-dependent ethylene-producing micro-organisms, e.g. Cryptococcus albidus. Ethyleneforming enzymes have been purified to electrophoretic homogeneity from both $P$. digitatum (Fukuda et al., $1989 a$ ) and C. albidus (Fukuda et al., 1989c).

A number of ethylene-producing strains of bacteria have been reported and after a series of studies with Escherichia coli B SPAO, Primrose (1976, 1977) proposed that KMBA was an intermediate in ethylene biosynthesis. Ince \& Knowles (1986) showed that ethylene was

Abbreviation: KMBA, 2-keto-4-methylthiobutyric acid. synthesized by a cell-free extract of $E$. coli B SPAO incubated with KMBA, NAD(P)H, Fe(III) chelated to EDTA and oxygen, and discussed the possibility that all bacterial ethylene production might occur via the route demonstrated for $E$. coli. The physiology and biochemistry of ethylene production by $E$. coli and by other selected bacteria, including a strain of Pseudomonas aeruginosa, has since been investigated further (Shipston \& Bunch, 1989: Mansouri \& Bunch, 1989).

The bacterium Pseudomonas syringae pv. phaseolicola PK2 (Kudzu strain), which in Japan causes halo blight of the viny weed Pueraria lobata (Willd) Ohwi (common name Kudzu), is known to produce ethylene (Goto et al., 1985). Goto \& Hyodo (1987) reported that ethylene was produced when a cell-free extract of this bacterium was incubated under aerobic conditions with $0.5 \mathrm{~mm}-2$ oxoglutarate, $0.5 \mathrm{~mm}-\mathrm{FeSO}_{4}, 10 \mathrm{~mm}$-L-histidine and $5 \mathrm{mM}$-DTT in $50 \mathrm{~mm}-\mathrm{HEPES} / \mathrm{NaOH}$ (pH 7.0). However, the ethylene-forming activity of this system was completely lost when the cell-free extract was dialysed against $10 \mathrm{~mm}$-potassium phosphate buffer $(\mathrm{pH} 7 \cdot 0)$ for $24 \mathrm{~h}$ at $4{ }^{\circ} \mathrm{C}$, indicating the loss, during dialysis, of a factor essential for enzymic activity. 
The purpose of this study was to identify the factor(s) essential for the ethylene-forming activity of Ps. syringae pv. phaseolicola and to construct an ethylene-forming system in vitro.

\section{Methods}

\begin{abstract}
Micro-organism and culture conditions. All experiments were done with Pseudomonas syringae pv. phaseolicola strain PK2. The strain was stored at $4{ }^{\circ} \mathrm{C}$ on NB medium containing $0.5 \%(\mathrm{w} / \mathrm{v})$ glucose and $2 \%$ (w/v) agar. NB medium comprised $0.5 \%$ Polypepton, $0.3 \%$ meat extract, $0.2 \%$ yeast extract and $0.2 \% \mathrm{NaCl}(\mathrm{pH} \mathrm{7.0)}$. A loopful of bacteria was inoculated into a $100 \mathrm{ml}$ Erlenmeyer flask containing $20 \mathrm{ml}$ of NB medium supplemented with $0.5 \%$ glucose and the resulting seed culture was grown up at $30^{\circ} \mathrm{C}$ on a rotary shaker, at 180 r.p.m., for $24 \mathrm{~h}$. Then $4 \mathrm{ml}$ of the seed culture was transferred to a $500 \mathrm{ml}$ Erlenmeyer flask containing $200 \mathrm{ml} 0.5 \%$ glucose in NB medium and placed on rotary shaker for 10-12 h under the same conditions as for the seed culture.
\end{abstract}

Preparation of cell-free extract. Cells were harvested from $900 \mathrm{ml}$ of culture broth by centrifugation at $14000 \mathrm{~g}$ for $10 \mathrm{~min}$. They were washed twice with deionized water and suspended in $90 \mathrm{ml} 10 \mathrm{mM}$ potassium phosphate buffer ( $\mathrm{pH} 7.0$ ). The cells were disrupted by sonication (Branson sonifier, model 350) for $5 \mathrm{~min}$ with $30 \mathrm{~s}$ intervals for cooling between each $30 \mathrm{~s}$ period of sonication. Intact cells and cell debris were removed by centrifugation $\left(24000 \mathrm{~g}\right.$, at $4{ }^{\circ} \mathrm{C}$ for $\left.30 \mathrm{~min}\right)$ and the supernatant obtained was used as the cell-free extract.

Preparation of partially purified enzyme and a low molecular mass fraction. The cell-free extract was concentrated by ultrafiltration on a DIAF YM 10 membrane (Amicon) to give two fractions, a crude enzyme fraction containing macromolecules with molecular masses $>10 \mathrm{kDa}$ and a fraction (SupI) containing substances with molecular masses $<10 \mathrm{kDa}$. The SupI fraction was concentrated by lyophilization and the optical density at $280 \mathrm{~nm}$ was adjusted by adding deionized water. The crude enzyme solution was applied to a gel-filtration column $(2.6 \times 80 \mathrm{~cm}$, gel volume $425 \mathrm{ml})$ of Sephadex G-75 (Pharmacia) equilibrated with $50 \mathrm{mM}$-potassium phosphate buffer $(\mathrm{pH} \mathrm{7 \cdot 0)}$ ). Eluted fractions that had ethylene-forming activity were pooled. This pool was termed Fraction I and was used as partially purified enzyme.

Ethylene formation. This was determined using a modified version of the reaction mixture of Fukuda et al. (1986) and of Goto \& Hyodo (1987), containing: $0.2 \mathrm{ml} 200 \mathrm{~mm}-\mathrm{HEPES} / \mathrm{NaOH}$ buffer ( $\mathrm{pH} \mathrm{8.0)}$ ), $0.1 \mathrm{ml} 5 \mathrm{~mm}$-2-oxoglutarate, $0.1 \mathrm{ml} 0.75 \mathrm{~mm}-\mathrm{FeSO}_{4}, 0.1 \mathrm{ml} 20 \mathrm{~mm}$ DTT, $0 \cdot 1 \mathrm{ml} 100 \mathrm{~mm}$-L-histidine, $0.2 \mathrm{ml}$ of deionized water and $0.1 \mathrm{ml}$ of enzyme solution. A test-tube (15 mm diameter, $13 \mathrm{ml}$ capacity) containing the reaction mixture $(1 \mathrm{ml})$ was sealed with a rubber stopper and then incubated on a reciprocal shaker $(120$ r.p.m. $)$ at $25^{\circ} \mathrm{C}$ for $10 \mathrm{~min}$. In the case of ethylene production by living cells, culture broth $(1 \mathrm{ml})$ was transferred to a sterile test-tube $(18 \mathrm{~mm}$ diameter, $34 \mathrm{ml}$ capacity). The test-tube was sealed with a rubber stopper and then incubated on a reciprocal shaker $\left(120\right.$ r.p.m.) at $30^{\circ} \mathrm{C}$ for $1 \mathrm{~h}$. After incubation, a sample of gas $(1 \mathrm{ml})$ was withdrawn through the stopper with a gas syringe and the amount of ethylene in the sample was determined with a gas chromatograph (G3800; Yanako) under the following conditions: column size, $3 \mathrm{~mm} \times 2 \mathrm{~m}$; solid phase, active alumina; temperature, $100^{\circ} \mathrm{C}$; carrier gas, nitrogen (flow rate $40 \mathrm{ml}$ $\mathrm{min}^{-1}$ ); detection, flame ionization. The rate of ethylene formation was calculated as previously described (Fukuda et al., 1984).

Amount of cells. This was determined from the optical density at $610 \mathrm{~nm}$ or from the dry weight.
Glucose concentration. The concentration of glucose in supernatants was measured by the Glucose B-Test (Wako Pure Chemicals).

Protein concentration. This was measured as the absorbance at $280 \mathrm{~nm}$ or by the Lowry method with BSA as the standard.

\section{Results}

\section{Effect of SupI addition on ethylene-forming activity}

The ethylene-forming activities of cell-free extract, treated by dialysis for $24 \mathrm{~h}$ at $4{ }^{\circ} \mathrm{C}$, the crude enzyme fraction and the SupI fraction (obtained by ultrafiltration; see Methods), were measured (Table 1). The modified in vitro system of Fukuda et al. (1986) and Goto \& Hyodo (1987) was used for measurements of ethyleneforming activity. Activities recovered, as a percentage of total activity, of the crude enzyme and cell-free extract after dialysis were $49 \%$ and $3 \%$ of the total activity in the cell-free extract, respectively. However, the activities recovered after addition of SupI to the crude enzyme fraction and the cell-free extract after dialysis increased to $87 \%$ and $25 \%$ of the total activity in the cell-free extract. Reactivation of the system may be more complex in the case of dialysed extract, because of inactivation of the enzyme occurred during dialysis, and the activity of dialysed extract was very low. Anyhow, this result indicates the presence of a factor in SupI that is essential for ethylene-forming activity. This factor was stable to heating at $121^{\circ} \mathrm{C}$ for $5 \mathrm{~min}$ (see Table 1). Therefore, the essential component is heat-stable and has a moleuclar mass $<10 \mathrm{kDa}$.

\section{Table 1. Effects on ethylene-forming activity of the addition of} SupI to various fractions

The volume of enzyme solution used was $10 \mathrm{ml}$ in all cases. The protein concentration of cell-free extract was $9.59 \mathrm{mg} \mathrm{ml}^{-1}$; it was dialysed, where indicated, against $10 \mathrm{~mm}$-potassium phosphate buffer ( $\mathrm{pH} \mathrm{7.0)}$ ) for $24 \mathrm{~h}$ at $4{ }^{\circ} \mathrm{C}$. Crude enzyme is the fraction of cell-free extract which was concentrated on a DIAF YM 10 ultrafiltration membrane; the solution was made up to $10 \mathrm{ml}$ with $10 \mathrm{~mm}$-potassium phosphate buffer, $\mathrm{pH} 7.0$. SupI is the fraction with a molecular mass $<10 \mathrm{kDa}$ which passed through a DIAF YM 10 membrane; the protein concentration of added SupI was $1.08 \mathrm{mg} \mathrm{ml}^{-1}$.

\begin{tabular}{lccr}
\hline \hline \multicolumn{1}{c}{$\begin{array}{c}\text { Enzyme } \\
\text { source }\end{array}$} & $\begin{array}{c}\text { SupI } \\
\text { added }\end{array}$ & $\begin{array}{c}\text { Ethylene-forming } \\
\text { activity } \\
\left(\mathrm{nl} \mathrm{ml}^{-1} \mathrm{~h}^{-1}\right)\end{array}$ & $\begin{array}{c}\text { Relative } \\
\text { activity } \\
(\%)\end{array}$ \\
\hline $\begin{array}{l}\text { Cell-free extract } \\
\text { Crude enzyme }\end{array}$ & - & 1522 & 100 \\
$\begin{array}{l}\text { Cell-free extract } \\
\text { after dialysis }\end{array}$ & - & 748 & 49 \\
$\begin{array}{l}\text { Crude enzyme } \\
\text { Crude enzyme }\end{array}$ & + & 49 & 3 \\
$\begin{array}{l}\text { Cell-free extract } \\
\text { after dialysis }\end{array}$ & $+*$ & 1319 & 87 \\
\hline \hline
\end{tabular}

* Heat-treated $\left(121^{\circ} \mathrm{C}, 5 \mathrm{~min}\right)$ SupI was used. 


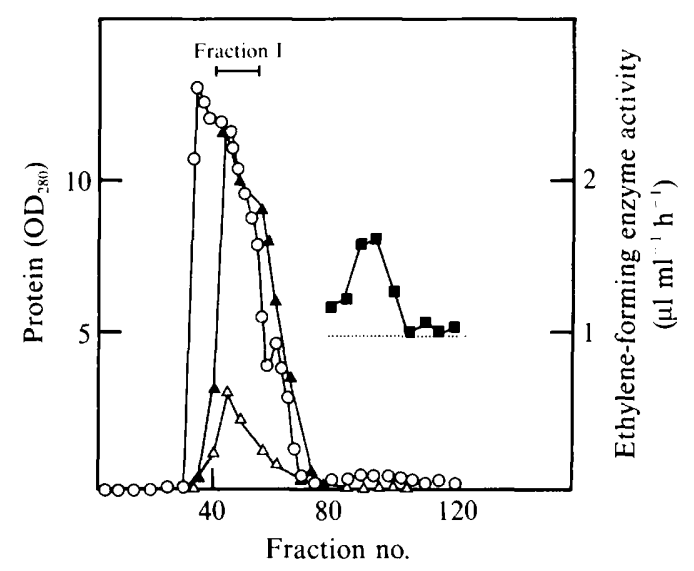

Fig. 1. Elution from a column of Sephadex G-75 of crude enzyme from Ps. syringae pv. phaseolicola $\mathrm{PK} 2$. The fraction vol. was $4 \mathrm{ml}$. The protein content $(O)$ of each fraction, together with the ethyleneforming activities of $(\triangle)$ partially purified enzyme, $(\mathbf{A})$ partially purified enzyme plus SupI and ( $\square$ ) fractions from 80-120 plus Fraction I are shown. Fraction I comprises fractions $40-59$ that have activity in the ethylene-forming assay. The protein concentration of SupI used was $11.65 \mathrm{mg} \mathrm{ml}^{-1}$.

\section{Chromatography on Sephadex G-75 of crude enzyme}

In order to obtain a partially purified enzyme without the SupI fraction, gel filtration on a column of Sephadex G75 was performed using a solution of crude enzyme that had been concentrated about ten-fold by ultrafiltration (Fig. 1). The ethylene-forming activity of the enzyme was very low and the activity recovered was about $21 \%$ of that of the crude enzyme. The total ethylene-forming activity after addition of SupI was about four times that without SupI. Fractions 40-59 were pooled as the ethylene-forming enzyme fraction (termed Fraction I). Fraction I was added to each fraction from 80-120, and from a comparison of the activities of Fraction I alone, and of the combined fraction, it was found that a compound with properties similar to those of SupI was present in fractions 80-100. To determine the essential factor in SupI, its properties were examined, and found to be as follows: ninhydrin-positive, dialysable and heatstable. The essential factor was considered, therefore, to be a peptide or an amino acid.

Next we examined the effects of the addition of Polypepton, meat extract, yeast extract, NZ amine (Wako Pure Chemicals) and Casamino acids (vitaminfree) to Fraction I. Since all these additives were effective (data not shown), amino acids were added separately to the reaction mixture (Table 2). It was found that SupI could be essentially replaced by L-arginine.
Table 2. Effects of amino acids on the ethylene-forming activity of Fraction I

The reaction mixture contained $40 \mathrm{~mm}-\mathrm{HEPES} / \mathrm{NaOH}$ buffer (pH 8.0), $0.075 \mathrm{~mm}$-FeSO, $2 \mathrm{~mm}$-DTT, $10 \mathrm{~mm}$-histidine and $0.5 \mathrm{~mm}$-2-oxoglutarate. The concentration of Fraction I protein in each reaction mixture was $0.99 \mathrm{mg} \mathrm{ml}^{-1}$. The concentrations of amino acids and Casamino acids were $1 \mathrm{~mm}$ and $1 \mathrm{mg}$ per reaction mixture, respectively.

\begin{tabular}{lclc}
\hline $\begin{array}{c}\text { Amino-acid } \\
\text { added }\end{array}$ & $\begin{array}{c}\text { Ethylene-forming } \\
\text { activity } \\
\left(\mathrm{nl} \mathrm{m}^{-1} \mathrm{~h}^{-1}\right)\end{array}$ & $\begin{array}{c}\text { Amino acid } \\
\text { added }\end{array}$ & $\begin{array}{c}\text { Ethylene-forming } \\
\text { activity } \\
\left(\mathrm{nl} \mathrm{ml}^{-1} \mathrm{~h}^{-1}\right)\end{array}$ \\
\hline Glycine & 294 & L-Tryptophane & 251 \\
L-Alanine & 271 & L-Tyrosine & 228 \\
L-Valine & 251 & L-Asparagine & 261 \\
L-Leucine & 280 & L-Glutamine & 341 \\
L-Isoleucine & 278 & L-Aspartic acid & 256 \\
L-Phenylalanine & 246 & L-Glutamic adid & 253 \\
L-Proline & 249 & L-Lysine & 194 \\
L-Serine & 278 & L-Arginine & 3079 \\
L-Threonine & 266 & L-Histidine & 239 \\
L-Cysteine & 109 & Casamino acids & 1580 \\
L-Methionine & 249 & None & 298 \\
\hline \hline
\end{tabular}

\section{Reconstruction of an ethylene-forming system in vitro}

The optimal concentrations of the compounds required for the formation of ethylene by the partially purified enzyme were determined (Fig. 2). The optimal concentrations of 2-oxoglutarate, $\mathrm{FeSO}_{4}$, DTT, L-histidine and $\mathrm{L}$-arginine were $0 \cdot 25,0 \cdot 2,2,10$ and $0.2 \mathrm{mM}$, respectively. We were able to reconstruct an ethylene-forming system in vitro using the partially purified enzyme from $P s$. syringae pv. phaseolicola PK2. The standard reaction mixture, incubated under aerobic conditions, contained the following: $0.2 \mathrm{ml} 200 \mathrm{mM}-\mathrm{HEPES} / \mathrm{NaOH}$ buffer (pH 8.0), $0.1 \mathrm{ml} 2.5 \mathrm{~mm}$-2-oxoglutarate, $0.1 \mathrm{ml} 2 \mathrm{mM}$ $\mathrm{FeSO}_{4}, 0.1 \mathrm{ml} 20 \mathrm{~mm}$-DTT, $0.1 \mathrm{ml} 100 \mathrm{~mm}$-L-histidine, $0.1 \mathrm{ml} 2 \mathrm{mM}$-L-arginine, $0.2 \mathrm{ml}$ of deionized water and $0.1 \mathrm{ml}$ of enzyme solution (total vol. $1.0 \mathrm{ml}$ ).

In order to ascertain the necessity for ethylene formation of each component of the standard reaction mixture, each compound separately was omitted from the mixture (Table 3). The presence of 2-oxoglutarate, $\mathrm{Fe}^{2+}$ and L-arginine was essential and DTT and Lhistidine markedly stimulated the reaction.

\section{Effects of the addition of analogues of L-arginine and L-histidine on ethylene formation}

The cofactor specificity of the ethylene-forming enzyme was examined by replacing L-arginine or L-histidine with various compounds (Table 4). Ethylene-forming activity in the presence of $\mathrm{D}$-arginine and L-canavanine was $11 \%$ 


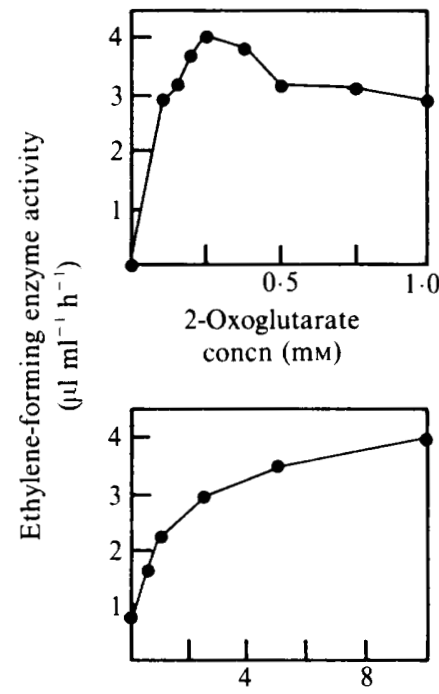

L-Histidine concn (mM)

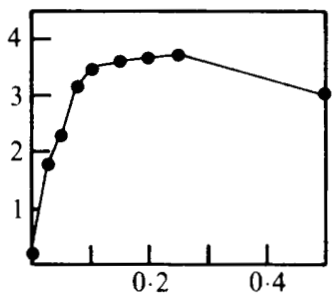

$\mathrm{FeSO}_{4}$ concn $(\mathrm{mM})$

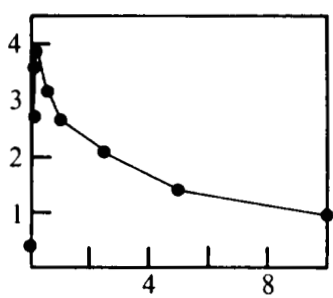

L-Arginine concn $(\mathrm{mm})$

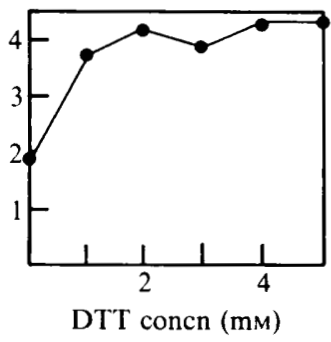

DTT concn (mM)

Fig. 2. Effects of varying the concentrations of essential components in the reaction system. When the concentration of one component was changed, those of the others were fixed as follows: $0.25 \mathrm{~mm}$-2-oxoglutarate, $2 \mathrm{~mm}$-DTT, $0.2 \mathrm{~mm}-\mathrm{FeSO}_{4}, 10 \mathrm{~mm}-\mathrm{L}$-histidine and $0.2 \mathrm{mM}-\mathrm{L}$-arginine. The concentration of Fraction I protein added to each reaction mixture was $0.99 \mathrm{mg} \mathrm{ml}^{-1}$.

Table 3. Effects of omission of each component from the standard reaction mixture on the ethylene-forming activity of

\section{Fraction I}

The components of each reaction mixture were the same as those in the standard reaction mixture except for the omission of the cited component. The concentration of Fraction I protein in each reaction mixture was $0.99 \mathrm{mg} \mathrm{ml}^{-1}$.

\begin{tabular}{lcc}
\hline $\begin{array}{c}\text { Component } \\
\text { omitted }\end{array}$ & $\begin{array}{c}\text { Ethylene-forming } \\
\text { activity } \\
\left(\mathrm{nl} \mathrm{m}^{-1} \mathrm{~h}^{-1}\right)\end{array}$ & $\begin{array}{c}\text { Relative } \\
\text { activity } \\
(\%)\end{array}$ \\
\hline None & 4637 & 100 \\
2-Oxoglutarate & 0 & 0 \\
FeSO & 201 & 4 \\
DTT & 1852 & 40 \\
L-Histidine & 1114 & 24 \\
L-Arginine & 208 & 4 \\
Fraction I & 0 & 0 \\
\hline \hline
\end{tabular}

and $12 \%$, respectively, of that in the presence of $L-$ arginine. None of the L-histidine analogues tested could replace L-histidine, although imidazole enhanced ethylene-forming activity to a small extent.

\section{Comparison of the time-course of ethylene formation in} the cell-free system with that in living cells

The time-courses of ethylene formation both in the cellfree system (in vitro) and in living cells (in vivo) are shown in Fig. 3. The two time-courses were somewhat dissimilar, but the two peaks of the rate of ethylene
Table 4. Effects of the addition of analogues of $\mathrm{L}$-arginine or L-histidine on the ethylene-forming activity of Fraction I

The concentrations of components in each reaction mixture, except for L-arginine or L-histidine, were the same as in the standard reaction mixture. The concentration of Fraction protein in each reaction mixture was $0.99 \mathrm{mg} \mathrm{ml}^{-1}$.

\begin{tabular}{lccc}
\hline \hline $\begin{array}{c}\text { Compound } \\
\text { added }\end{array}$ & $\begin{array}{c}\text { Final } \\
\text { concn } \\
(\mathrm{mM})\end{array}$ & $\begin{array}{c}\text { Ethylene-forming } \\
\text { activity } \\
\left(\mathrm{nl} \mathrm{ml}^{-1} \mathrm{~h}^{-1}\right)\end{array}$ & $\begin{array}{c}\text { Relative } \\
\text { activity } \\
(\%)\end{array}$ \\
\hline L-Arginine & $0 \cdot 2$ & 5618 & 100 \\
D-Arginine & $0 \cdot 2$ & 596 & 11 \\
L-Canavanine & $0 \cdot 2$ & 680 & 12 \\
Poly-L-arginine & $0 \cdot 2$ & 473 & 8 \\
None & & 375 & 7 \\
L-Histidine & $10 \cdot 0$ & 5021 & 100 \\
& $1 \cdot 0$ & 2961 & 59 \\
Histamine & $10 \cdot 0$ & 1602 & 32 \\
& $1 \cdot 0$ & 1351 & 27 \\
Imidazole & $10 \cdot 0$ & 1985 & 40 \\
None & $1 \cdot 0$ & 1284 & 26 \\
\hline \hline
\end{tabular}

formation almost coincided. We therefore believe the equivalent of this cell-free ethylene-forming system operates in living cells.

\section{Discussion}

In this work, we have described the construction of an ethylene-forming system in vitro using cell-free extracts of Ps. syringae pv. phaseolicola PK2. Although Goto \& 

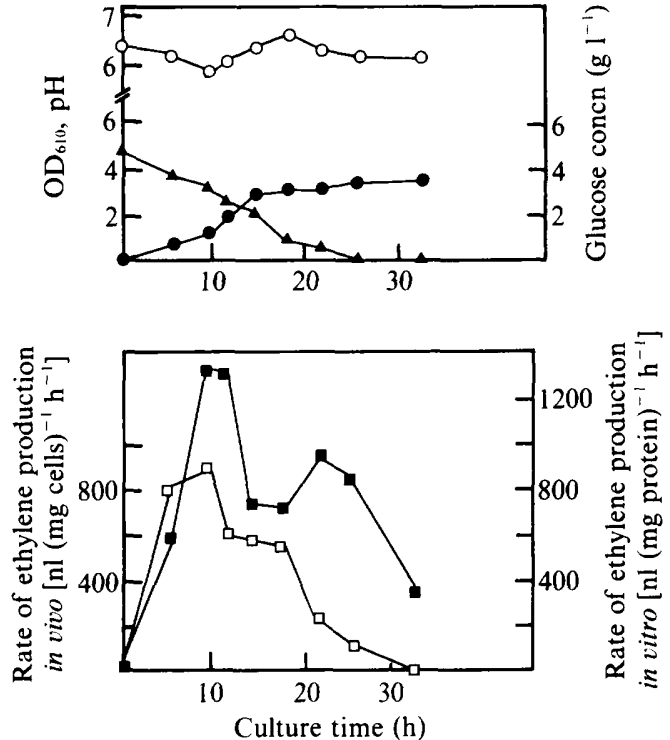

Fig. 3. Time-courses of ethylene formation by living cells and by the cell-free system. - Cell concentration $\left(\mathrm{OD}_{610}\right) ; \boldsymbol{\Delta}$, glucose concentration; $\mathrm{O}, \mathrm{pH} ; \square$, ethylene-forming activity of living cells: $\square$, ethyleneforming activity of the cell-free system.

Hyodo (1987) constructed an ethylene-forming system in vitro from this bacterium, the activity of the cell-free extract used was completely lost as a result of dialysis. This indicated that dialysable, low-molecular-mass substances present in cell-free extracts were essential factors for the ethylene formation. We tried to separate these low-molecular-mass substances from the cell-free extract, and we confirmed the existence of a factor with a molecular mass $<10 \mathrm{kDa}$ that was essential for ethylene formation. This factor could essentially be replaced by $\mathrm{L}-$ arginine (see Table 2). L-Arginine is also required as an essential component in an ethylene-forming system derived from $P$. digitatum (Fukuda et al., 1986). The ethylene-forming system derived from Ps. syringae pv. phaseolicola PK2 was similar to that from $P$. digitatum, with the exception of the stimulatory effect of $L$ histidine.

The requirement for L-arginine as well as for $\mathrm{Fe}(\mathrm{II})$ ions, 2-oxoglutarate and L-histidine is best understood, at this stage of our investigation, in terms of the hypothetical reaction mechanism described below, if we assume that the ethylene-forming enzymes from Ps. syringae pv. phaseolicola $\mathrm{PK} 2$ and $P$. digitatum act in a closely related manner. Under the optimum conditions (see Fig. 2), the concentrations of L-arginine, $\mathrm{Fe}(\mathrm{II})$ and 2-oxoglutarate are too low for these chemical species to interact with each other in bulk solution. This situation means, simply, that these species must be concentrated within certain domain(s) of the enzyme in some special way. Thus, the active site of the enzyme can be considered hypothetically as an $\mathrm{Fe}$ (II) complex bound to the enzyme through an appropriate ligand atom $Y$. The complex also binds L-arginine and 2-oxoglutarate as a Schiff-base structure to form an intermediate, as shown in Fig. 4(a).

The major role of L-histidine is most probably attributable to its imidazole ring, since imidazole itself accelerated the formation of ethylene to a small but significant extent. The ring may possibly coordinate with the intermediate $\mathrm{Fe}$ (II) complex, modifying the energy levels of $3 d$ electrons of $\mathrm{Fe}(\mathrm{II})$ so that it becomes easier to bind molecular oxygen. Then the intermediate reacts with oxygen to form an unstable $\mathrm{Fe}$ (IV) complex of the peroxo-type (see Fig. $4 b$ ), the 2-oxoglutarate moiety of which is decomposed to ethylene and three molecules of carbon dioxide. During these oxidation processes, Larginine, $\mathrm{L}$-histidine and $\mathrm{Fe}(\mathrm{II})$ are regenerated and, thus they can be regarded as cofactors from a mechanistic point of view. The chemical behaviour of the enzyme isolated from $P$. digitatum does not exclude this hypothetical mechanism, except that no relevant information is available about the imidazole ring included in the

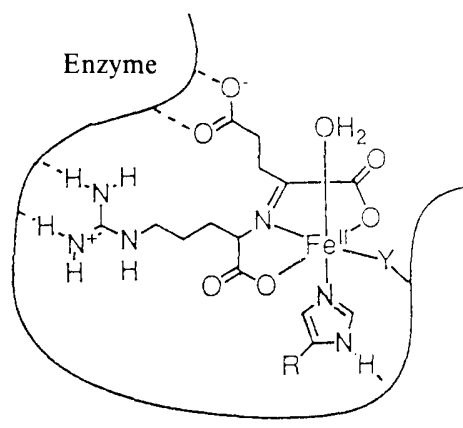

(a)

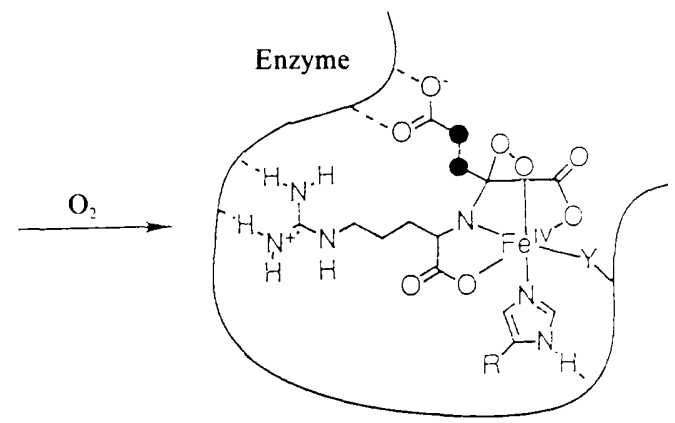

(b)

Fig. 4. Model of the proposed intermediate consisting of the ethylene-forming enzyme, 2-oxoglutarate, L-arginine and the imidazole compound. (a) The intermediate before reaction with oxygen and $(b)$ after reaction. The carbon atoms from 2-oxoglutarate that are converted to ethylene are indicated 
scheme in Fig. 4. The differences between the two enzymes are of great interest to us. Studies are now in progress on the further purification of the ethyleneforming enzyme, using the in vitro system described in this report, and on the biochemical mechanism of the formation of ethylene by Ps. syringae.

\section{References}

Fuxuda, H., FujII, T. \& Ogawa, T. (1984). Microbial production of $\mathrm{C}_{2}$-hydrocarbons, ethane, ethylene and acetylene. Agriculture and Biological Chemistry 48, 1363-1365.

FukUDA, H., FujII, T. \& OGaWA, T. (1986). Preparation of a cell-free ethylene-forming system from Penicillium digitatum. Agriculture and Biological Chemistry 50, 977-981.

Fukuda, H., Kitajima, H., Fuji, T., Tazaki, M. \& Ogawa, T. $(1989 a)$. Purification and some properties of a novel ethyleneforming enzyme produced by Penicillium digitatum. FEMS Microbiology Letters 59, 1-6.

Fukuda, H., Takahashi, M., Funi, T. \& Ogawa, T. (1989b). Ethylene production from L-methionine by Cryptococcus albidus. Journal of Fermentation and Bioengineering 67, 173-175.
Fukuda, H., Takahashi, M., Fuji, T., Tazaki, M. \& Ogawa, T. $(1989 c)$. An NADH:Fe(III)EDTA oxidoreductase from Cryptococcus albidus: an enzyme involved in ethylene production in vivo? FEMS Microbiology Letters 60, 107-112.

GoTo, M. \& HYODO, H. (1987). Ethylene production by cell-free extract of the Kudzu strain of Pseudomonas syringae pv. phaseolicola. Plant and Cell Physiology 28, 405-414.

Goto, M., Ishida, Y., TAKIKAWA, Y. \& Hyodo, H. (1985). Ethylene production by the Kudzu strains of Pseudomonas syringae pv. phaseolicola causing halo blight in Pueraria lobata (Willd) Ohwi. Plant and Cell Physiology 26, 141-150.

INCE, J. E. \& KNOWLES, C. J. (1986). Ethylene formation by cell-free extract of Escherichia coli. Archives of Microbiology 146, 151-158.

MANSOURI, S. \& BUNCH, A. W. (1989). Bacterial ethylene synthesis from 2-oxo-4-thiobutyric acid and from methionine. Journal of General Microbiology 135, 2819-2827.

Ogawa, T., Takahashi, M., Fujil, T., Tazaki, M. \& Fukuda, H. (1990). The role of NADH : Fe(III)EDTA oxidoreductase in ethylene formation from 2-keto-4-methylthiobutyrate. Journal of Fermentation and Bioengineering 69, 287-291.

Primrose, S. B. (1976). Ethylene production by Escherichia coli. Journal of General Microbiology 95, 159-165.

Primrose, S. B. (1977). Evaluation of the role of methionine, 2-keto-4methylthiobutyric acid and peroxidase in ethylene formation by Escherichia coli. Journal of General Microbiology 98, 519-528.

ShIPSTON, N. \& BunCH, A. W. (1989). The physiology of L-methionine catabolism to the secondary metabolite ethylene by Escherichia coli. Journal of General Microbiology 135, 1489-1497. 